\title{
THE MEDIATING EFFECT OF ORGANIZATIONAL COMMITMENT ON RELATIONSHIP BETWEEN FLEXIBLE WORKING AND JOB SATISFACTION: A RESEARCH IN LOGISTICS SECTOR
}

\author{
Fatma TÜRKMEN ${ }^{1}$, Nurten POLAT DEDE ${ }^{2}$
}

\begin{abstract}
The competitive environment caused by globalization lead to logistics companies to increase their service quality and implement best practices in order to meet customer demands and to reduce their supply times. The intensity of working hours and difficult working conditions makes the attracting and retaining of talented employees difficult for logistics firms. Therefore, the effect of flexible working arrangements on increasing job satisfaction and employee loyalty in the logistics sector becomes important. In this study, the effect of flexible working on employee's job satisfaction and the mediating role of organizational commitment in this effect were investigated. In the research, 82 employees' data used from 10 leading companies in their sectors implementing flexible working arrangements and the data were analyzed using SPSS 25.0 program. Flexible Working Scale developed by Albion (2004), Organizational Commitment Scale developed by Allen and Meyer (1990), Minnesota Job Satisfaction Scale developed by Weiss et al. (1967) were used to measure the attitudes of the employees. Research results show that there is a positive and meaningful relationship between flexible working and job satisfaction, between job satisfaction and organizational commitment. Furthermore, the results have shown that organizational commitment has a mediating role between flexible working and job satisfaction. In other words, as organizational commitment mediates in the relationship between flexible working and job satisfaction, as organizational commitment increases, job satisfaction also increases.
\end{abstract}

Keywords: Flexible Working, HRM in Logistics Sector, Job Satisfaction, Organizational Commitment

JEL Classification: J24, J28, J41,M51, M54

\section{ÖRGÜTSEL BAĞLILIĞIN ESNEK ÇALIŞMA VE ISŞ DOYUMU ILLIŞKISINDEKİ ARACILIK ETKİSi: LOJISTIK SEKTÖRÜNDE BİR ARAŞTIRMA}

\author{
Fatma TÜRKMEN, Nurten POLAT DEDE
}

Öz

Globalleşme ile artan rekabet ortamı lojistik firmalarının hizmet kalitelerini arttırmalarını ve tedarik sürelerinin azalması yönündeki müşteri taleplerini karşılayacak düzenlemeleri hayata geçirmelerine neden olmaktadır. Çalışma sürelerinin yoğunluğu, iş koşullarının zorluğu, yüksek turnover oranları, yetkin çalışanların bulunması ve tutundurulmasını güçleştirmektedir. $\mathrm{Bu}$ nedenle esnek çalışma düzenlemelerinin lojistik sektöründe iş doyumu ve çalışan bağlılığının arttırılmasındaki etkisi önem kazanmaktadır.

\footnotetext{
1 Fatma TÜRKMEN, Istanbul University, Institute of Social Sciences, Department of Business Administration, PhD Candidate for Management and Organization Program, Istanbul, Turkey, ftmturkmen@gmail.com ORCID:0000-0002-0657-684X

2 Asst. Prof. Nurten POLAT DEDE, Medipol University, Medipol Business School, Department of International Logistics Management, Istanbul, Turkey, ndede@ medipol.edu.tr, ORCID: 0000-0002-99524642
} 
$\mathrm{Bu}$ araştırmada esnek çalışmanın, çalışanın iş doyumuna etkisi ve bu etkide, örgütsel bağlılığın aracılık rolü araştırılmıştır. Araştırmada, esnek çalışma düzenlemelerini uygulayan sektörlerinde lider 10 şirketin 82 çalışanından bilgi formu ile değerlendirmeleri alınmış ve alınan bilgiler SPSS 25.0 programı kullanılarak analiz edilmiştir. Araştırmada çalışanların tutumlarını ölçmek için, Albion (2004) tarafından geliştirilen Esnek Çalışma Ölçeği, Allen ve Meyer (1990) tarafından geliştirilen 'Örgütsel Bağlılık Ölçeği', Weiss ve arkadaşları (1967) tarafından geliştirilen 'Minnesota İş Doyum Ölçeği' kullanılmıştır. Araştırma sonucuna dayanarak, esnek çalışma ile iş doyumu ve örgütsel bağlılık arasında, iş doyumu ile örgütsel bağlılık arasında pozitif bir ilişki tespit edilmiştir. Ayrıca, esnek çalışmanın, iş doyumu üzerindeki etkisinde, örgütsel bağlılığın aracılık rolü tespit edilmiştir. Başka bir deyişle, örgütsel bağlılık, esnek çalışma ve iş doyumu ilişkisinde aracıdır, örgütsel bağlılık arttıkça iş doyumu da artar.

Anahtar Sözcükler: Esnek Çalışma, Lojistik Sektöründe İKY, İş Doyumu, Örgütsel Bağlılık

Jel Sinıflaması: J24, J28, J41,M51, M54

\section{Introduction}

While flexible working arrangements continue to spread rapidly in developed countries, they have started to be introduced in many areas in developing countries. It is recognized that working hours and regulations in the workplace have a positive impact on business performance in terms of innovation, finance and even competition. Especially for the new generation, high technology-oriented, enterprises establishing flexible working arrangements will be the priority in preference.

Increasing trade volume with globalization has enlarged importance of logistics business for companies in the last few decades and has led to the rapid growth of companies operating in this field. Logistic activities are becoming more critical both in terms of competition and cost. Turkey, with intercontinental location has an important potential in this area. In addition to product and service quality, thanks to technological infrastructure, fast transfer, storing and customer satisfaction issues have become more important for companies. The necessity of long and intensive work hours for these activities is one of the most important features of this sector. Finding and retaining qualified employees to work in these conditions is one of the challenges of the sector. Therefore in this area with further growth potential, it is inevitable to adapt flexible working models in order to employ technology-oriented talented young people of our age.

In this study; the effects of flexible working on organizational commitment and job satisfaction and the role of organizational commitment in the relationship between flexible working and job satisfaction were examined.

In the first part of the study, flexible working and flexible working models, in the second part, the concept of job satisfaction, job satisfaction approaches and the factors affecting job satisfaction are discussed. In the third section, the concept of organizational commitment and organizational commitment approaches are explained as a result of the literature study. In the fourth section, the research section of the study is located. In this section, the validity and reliability of the data were analyzed and the degree and direction of the relationship between the variables were determined, and statistical results were given in detail. The study was completed with the results section where the data were evaluated. 


\section{Flexible working}

\subsection{Flexible Working Concept}

Flexibility can be defined as the capacity to adapt to change. In other words, an ability to respond to change (Michon, 1987), can be defined as the ability of a system and its subsystems to respond to needs (Boyer, 1990)

Atkinson in the definition of "dynamic flexibility"; changes in institutional, cultural and other social or economic regulations and practices that make the capacity to respond to change persistent and permanent (Atkinson, 1987).

Flexibility in business literature; refers to flexible arrangements both in organizational structuring and working conditions and in career planning and wage system (Seyyar \& Öz, 2007).

Flexibility in working life can be explained as the ability to adjust and adapt to developments and changes in economic, technological and other areas of life (Günay, 2004). In this respect, it is also possible to define flexibility not only as non-standard practices (new working models or changing working hours), but also as a new perspective on labour laws and practices through the fundamental changes required by the era (Ekin, 1999). However, it is considered as a current and important tool which is a remedy to unemployment and as an agreement and solution arising from the reconciliation of workers and employers during the difficult times of working life (Karakoyunlu, 1999).

As in many other innovations, emergency of flexible working models have been caused by changes in production processes and technology.These debates started especially after the economic and technological transformation and became widespread especially in the years of the 1973 Oil Crisis (Yavuz, 1995). The need to adapt to developments has led enterprises to renew themselves in production and employment processes and move to a more flexible management system (Günay, 2004).

With the effect of these policies, globalization gained momentum in the 1980s and the liberalization of capital markets and international trade, the flexibility of labor markets, the reduction of social expenditures, the reduction of taxes and the support of the private sector were taken as basis. In this period, rapid change in technology and automation in production increased.

As a result of technological developments and growing markets and production increase, the necessity of continuous production in enterprises has required a full-time work.

Flexible working models meet the needs of working life arising from economic and technological developments while helping to establish the balance between work and family (Stone, 2004).

Nowadays, the term "non-standard employment" is used more than the term "flexible employment". Non-standard employment represent that this type of work becomes an obligation for the employer rather than an option (Stone, 2004). For trade unions, flexibility means less job security, less wages and worse working conditions (Burchell, Ladipo, \& Wilkinson, 2002). 
According to this approach, flexible working arrangements will negatively affect trade union relations and ease of making arrangements in working conditions that are not in favor of employees will be provided. (Gilmore \& Williams, 2009).

\subsection{Types of Flexible Working}

There are various studies on the subject in the literature. One of these studies is used as internal and external flexibility (Atkinson, 1987) and (Rubery, Tarling, \& Wilkinson, 1987). Internal and external flexibility is also called functional and numerical flexibility. Wage flexibility and exclusion strategies were then added to this grouping. Meulders and Wilkin also offer a model of flexibility, which is similar but includes different categories

(Meulders \& Wilkin, 1987). In this model, wage and numerical flexibility are the same as those of Atkinson's model. Although similar to Atkinson's model, the third model has a wider scope with the newly added technical and organizational part (Meulders \& Wilkin, 1987). Working hours flexibility is also included in this model.

Taking these criticisms into consideration, new models have been developed to simplify this complexity associated with flexible working. Standing is one of those who propose a new model. Considering globalization, technological change and economic restructuring, Standing develops a flexibility model that includes five different types of flexibility: production or organizational flexibility, wage system flexibility, labor cost flexibility, business process flexibility (functional flexibility), business structure flexibility. Besides, Benner has divided flexibility into work flexibility and employment flexibility (Benner, 2002). Benner's flexibility in work expresses his ability to adapt to changes in production, employment and knowledge. Benner's employment flexibility, by contrast, refers to forms of employment (such as part-time, temporary and fixed-term employment, outsourcing, and employment agencies).

\subsection{Flexible Working Models}

Especially in developed countries, it is seen that different flexible working models are widely applied. Among the most common flexible working models in terms of working place, working time and working style; tele-work, work at home, part-time work, flexi-time, on-call work, subcontracting, subordinate work, loan work relationship, intensified weekly work, temporary work relationship (periodic work), job sharing, shift work, short work. Among these, part-time work is the most well-known and oldest flexible work model. And also the most common and applied flexible work arrangement is working at home. On the other hand, tele-work offers more opportunities for women, the disabled, the elderly and retired employees and at the same time contributes to the establishment of work-family balance. 


\section{Job satisfaction}

Job satisfaction is; satisfaction of the individual as a result of harmony with his / her work and workplace and also can be expressed as a positive attitude towards work (Karcioğlu, Timuroğlu, \& Çınar, 2009).

The first studies in this area began with Elton Mayo's Hawthorne research in the 1930s, and in the 1943s Maslow touched upon the relationship between satisfying needs and job satisfaction. Many researchers have tried to explain the job satisfaction.

According to Keith Davis, job satisfaction is the satisfaction or dissatisfaction of employees with their work (Davis, 1988). Hackman and Oldham define job satisfaction as the happiness of individuals from the work they do or satisfaction from the services they receive. Vroom defined job satisfaction as a pleasant or positive emotional state resulting from evaluating one's work or work experience (Ardıç \& Baş, 2001). Steers and Black defined job satisfaction as follows; a pleasant or positive emotional state resulting from a person's assessment of his or her work or experience (Steers \& Black, 1994). Kalleberg defines job satisfaction as the general emotional orientation of employees towards their workplace tasks (Kalleberg, 1977) as Bartel describes all of the employee's work emotions as a whole (Bartel, 1981). According to Bennett, job satisfaction refers to the level of positive perception of employees' work (Bennett, 1994). In addition to these approaches about job satisfaction, Beer's definition of job satisfaction reveals a broader scope. According to Beer, job satisfaction is attitude of employees towards workplaces, jobs, colleagues and other psychological objects in the workplace. A positive attitude to these elements indicates job satisfaction and a negative attitude to job dissatisfaction (Beer, 1964).

\subsection{Importance of Job Satisfaction}

Satisfaction or dissatisfaction has consequences that affect both employees and organizations as well as society. Employees' job satisfaction is positively reflected both to their happiness, to their organization and to society. Otherwise, it may lead to employee burnout, organizational conflicts and even negative consequences such as having unhappy citizens for the society. Job satisfaction affects the individual's entire life satisfaction.

It has been evaluated that the employee with high job satisfaction will contribute positively to the organization and the employees with low job satisfaction will harm the organization with situations such as not coming to work with excuses, indifference to work, ignoring the rules and values of the workplace and expressing complaints continuously. It is seen that job satisfaction is very important for the continuity of the organization, achieving its targets and performance in an environment where competition conditions are increasing (Akat \& Budak, 2002).

\subsection{Job Satisfaction Approaches}

Approaches explaining job satisfaction can be summarized as content and process motivations. 
Content Approaches: Maslow's Hierarchy of Needs, Herzberg's "Double Factor Theory", Alderfer's "ERG Theory" which work on factors that influence and direct human behaviors and argue that this is the desire of people to satisfy needs and desires.

McClelland's "Need for Success" and Fromm's "Theory of Needs" are theories working on the factors that influence and direct human behavior and advocate that it is the desire of people to satisfy their needs and desires.

Process Approaches: Process approaches explain the external factors that lead the individual to certain behaviors. Since they do not cover the motives and needs underlying the behaviors and motivations exhibited, they are composed of external factors given to the individual from the outside (Koçel, 2007).

Process Theories concentrate on specific psychological processes under behavior and the contınuum of perceiving actions that affect behavior (Schermerhorn \& Bond, 1997). Vroom's Expectation / Hope Theory ", Porter and Lawler's ekl Expectation Theory", Adams's "Rightness / Equality Theory" and Locke's "Diversity / Purpose Management Theory" approaches.

\subsection{Factors Affecting Job Satisfaction}

Job satisfaction is an important factor that directly affects employee performance. However, job satisfaction varies from person to person. Employees are motivated by different issues, some are affected by wages, some are affected by promotion, others are affected by working conditions and workplace relations in workplace and social factors. On the other hand, the job itself has been identified as the most affecting dimension of job satisfaction (Meral, 2018). Factors affecting job satisfaction are grouped under two headings.

Individual Factors Affecting Job Satisfaction: Personality traits, age, gender, marital status, education, occupation, seniority, status and socio-cultural environment are listed as accuracy and trust.

Organizational Factors Affecting Job Satisfaction: In addition to personal factors, a number of organizational factors are effective in the job satisfaction of the individual. Job itself, wage, promotion, working conditions, behaviors of colleagues, manager relations, communication, feedback, job security, decision making practices, equal rewards, appropriate working environment are among these factors.

\subsection{Results of Job Dissatisfaction}

Job dissatisfaction leads to the following disadvantages:

Decrease in Performance: The employee in this situation cannot make the necessary contribution willingly or unwillingly, wastes time on different subjects by disrupting his / her job and the quality of service decreases.

Increasing Disruptive Behaviors: Knowingly and voluntarily damaging the organization, obeying the rules, exhibiting aggressive behaviors to their superiors and colleagues cause destructive behaviors. 


\begin{abstract}
Absenteeism, Increasing Tendency to Work and Leaving Work: Increasing willingness to leave, coming or not coming to work, increasing labor turnover rate and consequently increasing costs.
\end{abstract}

Employee Moral Deterioration: This leads to employee morale deterioration and therefore inefficient work.

Health Expenditures: Psychology leads to disorders and health problems and thus health costs increase.

Stress: Job dissatisfaction and uncertainty cause stress and lead to health problems such as burnout syndrome.

\title{
4. Organizational Commitment
}

Organizational commitment can be defined as the degree to which the employee adopts the aims and norms of the organization and the affective commitment he / she feels towards the organization and the desire to stay in the organization.

According to Gouldner (1960), organizational commitment is conceptualized as a onedimensional and homogeneous structure. However, organizational commitment is not homogeneous nor a dimensionless variable, but rather multidimensional. In general, organizational behavior theorists focus on the attitudinal dimension of commitment, and social psychologists focus on the behavioral dimension of commitment and conduct research according to these two different perspectives.

In the multi-loyalty approaches, both behavioral and loyalty approaches are used. Although the values of each of the factor in the multi-loyalty approach are different for the individual, the structure of the personality and so on. Attitude towards each of them is different with the effect of individual characteristics (Bakır, 2013).

\subsection{Factors Affecting Organizational Commitment}

When the studies on the subject are examined, it is seen that different groupings are made, but the most common one is grouping as individual, organizational and non-organizational factors.

Individual Factors: More personal characteristics (gender, marital status, age, position, education, etc.) come to the forefront.

Organizational Factors: The feature and importance of the work, management and leadership style, organizational culture, wage justice, organizational climate, organizational trust, human resources management practices, audits, rewards, penalties if any, teamwork, role ambiguity and role conflict are expressed (Gündoğan, 2009).

Non-Organizational Factors: Depending on economic conditions, country conditions such as unemployment rate and the possibility of finding a job are the factors that affect employee loyalty (Gündoğan, 2009). 


\subsection{Organizational Commitment Approaches}

Allen and Meyer, March and Simon, Mowday, Steers and Porter, Boulian, while explaining commitment in terms of attitude, Becker, Staw, Salanick discussed the behavior of commitment. In later periods, as the third species, Reichers developed a multi-loyalty approach.

\subsection{Results Of Organizatıonal Commitment}

The most basic results of the level of organizational commitment; can be divided into two positive and negative results. The various consequences of organizational commitment are assessed below.

\section{Organizational Commitment and Performance:}

Employees with a high commitment to the organization are expected to increase their performance as they have a high sense of responsibility and will be more diligent with their job awareness. (Mathieu \& Zajac, 1990).In addition, there should be supportive factors such as employee personality traits, reward approach, and sense of equality.

Organizational Commitment and Intention to Leave: There is an inverse relationship between intention to quit and commitment to the organization. As the commitment increases, the rate of turnover decreases.

Organizational Commitment and Stress: Low level of organizational commitment and stressful working environment can cause job dissatisfaction and even quitting (Mathieu \& Zajac, 1990).

Organizational Commitment and Absenteeism: As an employee's negative behavior; it is defined as not coming to work during normal working hours. Employees with strong organizational ties do not exhibit such negative behavior.

\subsection{Organizational Commitment And Job Satisfaction}

While organizational commitment has positive emotions and attitudes towards the organization of the employee, job satisfaction can be expressed as the relationship between the employee and the business environment. Also job satisfaction is one of the important factors leading to organizational commitment (Meral, 2018).

Porter, Steers, Mowday, Boulian, and Steven (1978) conducted a study on job satisfaction and organizational commitment, and as a result of the research, they obtained a linear relationship between these two variables. It is stated that if employees' perception of job satisfaction is high, their organizational commitment will be high.

McIntyre et al; (2002) conducted a study examining organizational commitment and job satisfaction in the working group. Similarly, they found that job satisfaction had a significant and strong impact on organizational commitment.

\section{Research Methodology}

In this section, the purpose, model, method and findings of the research are given. 


\subsection{Purpose of The Research}

The main purpose of this study is to determine the effect of flexible working on job satisfaction and the role of organizational commitment in this effect. In addition to this basic purpose, the participants' perception of flexible working; attitudes towards job satisfaction and organizational commitment; The relationships between flexible working, job satisfaction and organizational commitment were also investigated.

\subsection{Research Model}

The model of the research is given in Figure 1.

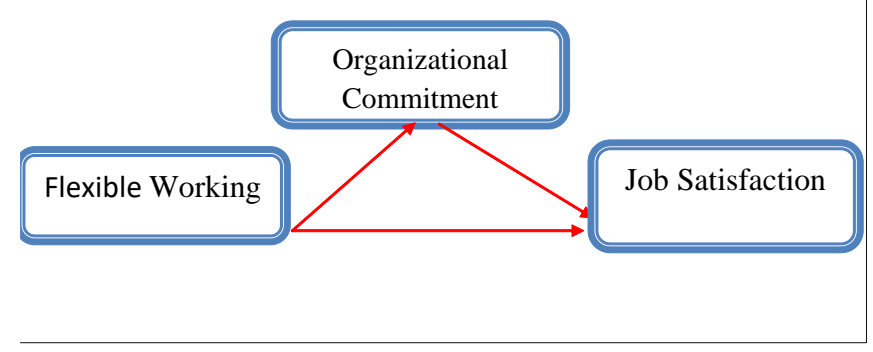

Figure 1. The model of the research

\subsection{Hypotheses of The Research}

The hypotheses of the research are as follows:

H1: Flexible working positively affects employees' commitment to the organization.

$\mathrm{H} 2$ : Flexible working positively affects the job satisfaction of the employees.

H3: Organizational commitment has a mediating role in the effect of flexible working on job satisfaction.

\subsection{Scales Used in The Study}

The Flexible working Scale developed by (Albion, 2004) was used to determine the attitudes and perceptions of employees regarding flexible working arrangements.

Organizational Commitment Scale developed by Allen and Meyer (1990) used to measure the organizational commitment of the employees was used.

The Minnesota Job Satisfaction Scale (Weiss, Dawis, England, \& Lofquist, 1967) developed by Weiss et al. (1967) to measure job satisfaction was used.

\subsection{Activities For Providing Validity And Reliability}

Factor analysis was applied to the scales used in the study to determine the factor structures and structure validity has been revealed. 
Factor analysis is a multivariate statistical analysis aimed at obtaining a small number of identifiable and significant variables from multiple variables measuring the same structure (Büyüköztürk, 2011).

In this context, principal components and varimax rotation methods have been used because of the fact that the factors are suggested in the analyzes based on the idea that they are related to each other. In order to determine whether the scales have internal consistency, reliability analysis was performed and Cronbach's Alpha reliability values were calculated for overall reliability and reliability of the sub-dimensions.

Correlation matrix, Barlett test and Kaiser-Meyer Olkin test are used to assess the suitability of the data set for factor analysis.

If the $\mathrm{p}$ value of Barlett test is $\mathrm{p}<0.05$, it is accepted that there is a relationship between the variables (Büyüköztürk, 2011). KMO sampling adequacy tests the correlation between the variables and factor analysis and the lowest acceptable limit is 0.50 . Generally accepted KMO values and comments are as follows: (0.5-weak, 0.6-medium, 0.7-good, 0.8-very good, 0.9excellent)

\subsection{Validity Analysis of Scales}

Flexible Working Scale: The KMO value was found to be 0.766 and the Bartlett sphericity test was over 0.50 and 0.05 significance level, so the data set was found to be suitable for factor analysis. It is based on the criterion that the variance explanation ratio is 0.50 and above. Total explained variance was found as $62,760 \%$. The reliability of the scale in the work life balance subscale was 0.892 , it was found to be very reliable, the reliability of the barriers subscale was 0.760 and the scale was found to be reliable. The Cronbach's Alpha value indicates that the scale has internal consistency.

Organizational Commitment Scale: The KMO value was found to be 0.828 , and since Bartlett's sphericity test was over 0.50 and it was significant at a significance level of 0.05 , the data set was found to be appropriate for factor analysis. Total explained variance was found as $66,740 \%$. The reliability of the scale in the affective commitment sub-dimension was 0.933 , it was found to be perfectly reliable, its reliability in the continuation commitment sub-dimension was 0.619 , and it was found to be moderately reliable, the reliability of the normative commitment sub-dimension was 0.572 and remained below the acceptable value of 0.6 . Accordingly, only the variables of affective commitment and continuation commitment were included in the study.

Job Satisfaction Scale: The KMO value was found to be 0.842 , which is the acceptable limit. The KMO coefficient found shows that the data are suitable for analysis. It is based on the criterion that the variance explanation ratio is 0.50 and above. Total explained variance was found to be $69,497 \%$. The internal consistency coefficient Cronbach mads Alpha value was calculated to calculate the reliability of the 20 items in the scale. The reliability of the external saturation subscale of the scale was 0.891 , it was found to be highly reliable, the reliability of the internal saturation subscale was 0.875 and the scale was found to be very reliable.

According to the results of exploratory factor analysis, there are two factors with eigenvalue greater than 1. Accordingly, it was determined that the scale consisted of two dimensions. The Cronbach's Alpha value indicates that the scale has internal consistency. 


\subsection{Methodology}

Quantitative analysis method was used for data analysis. The method of quantitative analysis is described as analysis of the data collected for the purposes of the research by making a statistical analysis and thus reaching the findings (Dawson, 2015). For this purpose, Statistical Program for Social Scientists (SPSS 25.0) was used.

The main focus of the research is all flexible working employees. However, since it is not possible to reach all of them, the employees of the institutions with flexible working practices that can be reached and obtained permission were taken as samples.

The research was carried out with 82 information forms that were accessed and received by email, online login or printout from the employees who were contacted and wished to participate.

The 82 questionnaires obtained as a result of the study performed by easy sampling method are suitable for acceptable sample sizes (Altunışık, 2010).

The descriptive analyzes of the research were carried out with descriptive methods such as median, standard deviation, frequency and percentage. Pearson Correlation analysis and linear regression analysis were used to determine relationships and effects. Intermediary variable analysis was based on Baron and Kenny's mediation effect analysis method. Sobel test statistic was used to test whether the role of the mediator variable was significant in predicting the dependent variable of the independent variable. The significance level of all analyzes was $p$ $<0.05$; confidence interval was accepted as $95 \%$.

Correlation and regression analyzes were performed by examining the skewness and kurtosis values of the distribution of normality.

In the studies carried out in social sciences, instead of Shapiro Wilk and similar normality tests, it is suggested that these values should be examined and these values should be in the range of $\pm 1,50$ and interpreted as normal distribution (Tabachnick \& Fidell, 2013). All skewness kurtosis values obtained in the study were within the range of $\pm 1,50$ (Table 1.).

Table 1. Skewness Kurtosis Values

\begin{tabular}{|l|l|l|}
\hline Scale / Sub Dimension & skewness & kurtosis \\
\hline Flexible working & & \\
\hline Work-Life Balance & $-0,838$ & 0,841 \\
\hline Barriers & $-0,363$ & $-0,067$ \\
\hline Organizational Commitment & & \\
\hline Affective C. & $-0,718$ & 0,177 \\
\hline Continuance C & $-0,362$ & $-0,116$ \\
\hline Job Satisfaction & & \\
\hline Internal JS & $-0,434$ & $-0,449$ \\
\hline External JS & $-0,491$ & $-0,170$ \\
\hline
\end{tabular}




\section{Findings}

In this section, the findings obtained as a result of the analysis of the data are presented as subheadings.

\subsection{Demographic Findings}

In this section, the findings obtained as a result of the analysis of the data are presented as subheadings. Findings related to gender, age, education and marital status of the participants are given below.

A total of 82 employees, $62(75.6 \%)$ male and 20 (24.4\%) female, participated in the study. According to age groups, $25.6 \%$ of participants were under 20 years old, $14.6 \%$ between 20-30 years old, 34\%, between $31-40$ years old, $23.2 \%$ between $41-50$ years old and 2, $4 \%$ are 51 years and older.

$45,1 \%$ of the participants are high school / vocational high school graduates, 32,9\% are university graduates, $20,7 \%$ are master degree and $1.2 \%$ are $\mathrm{PhD}$ graduates. Again, $63.4 \%$ of the participants were married, $36.4 \%$ were single and $42.7 \%$ had no children; $22 \%$ have one, $29 \%$ have two, $6 \%$ have more than 2 children. Accordingly, $26.8 \%$ of the participants had less than 5 years, $25 \%$ years of $5-10$ years, $14 \%$ years of $11-15$ years and $32 \%$, of them had a total seniority of 16 years and over.

41.5\% of the participants are Factory employee, $34.1 \%$ are General Directorate employee , $13.4 \%$ are Branches or Offices employee and 11\% are Regional Directorates employee.

When the monthly salary are examined, 50\% of the participants are receiving 2.200-5.000 TL, $35 \%$ of $5.000-10.000 \mathrm{TL}, 11 \%$ are receiving more than $10.000 \mathrm{TL}$ and $2.6 \%$ of them have minimum wage.

\subsection{Relationships between Flexible Work, Job Satisfaction and Organizational Commitment}

Correlation findings showing the relationships between flexible work, job satisfaction and organizational commitment are given in Table 2. 
Table 2. Correlation Findings between Flexible Working, Job Satisfaction and Organizational Commitment

\begin{tabular}{|c|c|c|c|c|c|c|c|}
\hline & & 1 & 2 & 3 & 4 & 5 & 6 \\
\hline \multirow{2}{*}{$\begin{array}{l}\text { Flexible working } \\
\text { (Work-Life Balance) }\end{array}$} & $\mathbf{r}$ & 1 & 0,197 & 0,199 &, $283 * *$ &, $400 * *$ &, $276 *$ \\
\hline & $\mathbf{p}$ & & 0,076 & 0,074 & 0,010 & 0,000 & 0,012 \\
\hline \multirow{2}{*}{$\begin{array}{l}\text { Flexible working } \\
\text { (Barriers) }\end{array}$} & $\mathbf{r}$ & & 1 & 0,107 & 0,133 & ,290** & 0,096 \\
\hline & $\mathbf{p}$ & & & 0,337 & 0,232 & 0,008 & 0,393 \\
\hline \multirow{2}{*}{ Job Satisfaction (External ) } & $\mathbf{r}$ & & & 1 &, $572 * *$ & ,413** &, $259 *$ \\
\hline & $\mathbf{p}$ & & & & 0,000 & 0,000 & 0,019 \\
\hline \multirow{2}{*}{ Job Satisfaction (İnternal ) } & $\mathbf{r}$ & & & & 1 &, $551 * *$ &, $386 * *$ \\
\hline & $\mathbf{p}$ & & & & & 0,000 & 0,000 \\
\hline \multirow{2}{*}{$\begin{array}{l}\text { Organizational } \\
\text { Commitment (Affective) }\end{array}$} & $\mathbf{r}$ & & & & & 1 &, $316 * *$ \\
\hline & $\mathbf{p}$ & & & & & & 0,004 \\
\hline \multirow{2}{*}{$\begin{array}{l}\text { Organizational } \\
\text { Commitment (Continuance) }\end{array}$} & $\mathbf{r}$ & & & & & & 1 \\
\hline & $\mathbf{p}$ & & & & & & \\
\hline
\end{tabular}

* Correlation is significant at $p<0.05$.

** Correlation is significant at $p<0.01$.

According to the analysis results;

There is a significant $(\mathrm{p}<0.05)$, positive and low $(\mathrm{r}=0.283 ; \mathrm{r}=0.276)$ relationship between Flexible Working (Work-Life Balance) and internal Job Satisfaction and continuance commitment. Flexible working (Work-Life Balance) had a significant ( $p<0.05$ ), positive and moderate $(r=0.400)$ relationship with affective commitment. In this case, as the work-life balance increases, internal job satisfaction and continuance commitment increases at a lower level, while affective commitment increases moderately.

There is a significant $(\mathrm{p}<0.05)$, positive and low $(\mathrm{r}=0.290)$ relationship between Flexible Working (Barriers) and affective commitment. Affective commitment increases as flexible working does not interfere with career development and job relationships.

There is a significant $(\mathrm{p}<0.05)$, positive and moderate $(\mathrm{r}=0.572 ; \mathrm{r}=0.413)$ relationship between external job satisfaction and internal job satisfaction and affective commitment. There was a significant $(\mathrm{p}<0.05)$, positive and low $(\mathrm{r}=0.259)$ relationship between external job satisfaction and continuance commitment. As external job satisfaction increases, internal job satisfaction and affective commitment increase moderately, while continuance commitment increases at a low level.

- There is a significant $(\mathrm{p}<0.05)$, positive and moderate $(\mathrm{r}=0.316)$ relationship between affective commitment and continuation commitment. As affective commitment increases, continuity commitment increases. 


\subsection{The Effect of Flexible working on Organizational Commitment}

Table 3. presents the regression findings that demonstrate the impact of Flexible Working on Organizational Commitment.

Table 3.The Effect of Flexible Working on Organizational Commitment

\begin{tabular}{|c|c|c|c|c|c|}
\hline \multirow{2}{*}{$\begin{array}{l}\text { Regression Model } \\
(\mathrm{r}=0,430 ; \mathrm{r} 2=0,185 \\
\mathrm{F}=18,126 ; \mathrm{p}=0,000)\end{array}$} & \multicolumn{2}{|c|}{ Non-Standardized Parameters } & $\begin{array}{l}\text { Standardized } \\
\text { Parameters }\end{array}$ & \multirow[t]{2}{*}{$\mathrm{t}$} & \multirow[t]{2}{*}{$\mathrm{p}$} \\
\hline & B & standard error & $\beta$ & & \\
\hline Constant & 2,063 & 0,405 & & 5,096 & 0,000 \\
\hline Flexible working & 0,450 & 0,106 & 0,430 & 4,257 & 0,000 \\
\hline
\end{tabular}

* Dependent Variable: Organizational Commitment

Accordingly, flexible working has a significant effect on affective commitment $(\mathrm{t}=4,257 ; \mathrm{p}=$ $0,000)$. The regression equation between flexible working $(\mathrm{X})$ and organizational commitment (Y) was found to be $\mathrm{Y}=2,063+0,450 \mathrm{X}$.

Flexible working, which is an independent variable, explains $18.5 \%$ of the organizational commitment which is a dependent variable. Based on this result, the hypothesis "H1:"Flexible working positively affects employees' commitment to the organization "is not statistically rejected.

\subsection{The Effect of Flexible Working on Job Satisfaction}

Table 4. shows the regression findings showing the effect of flexible working on job satisfaction.

Table 4. The Effect of Flexible Working on Job Satisfaction

\begin{tabular}{|l|l|l|l|l|l|}
\hline $\begin{array}{l}\text { Regression Model } \\
(\mathrm{r}=0,265 ; \mathrm{r} 2=0,070 \\
\mathrm{F}=6,021 ; \mathrm{p}=0,016)\end{array}$ & $\begin{array}{l}\text { Non-Standardized } \\
\text { Parameters }\end{array}$ & $\begin{array}{l}\text { Standardized } \\
\text { Parameters }\end{array}$ & $\mathrm{t}$ & $\mathrm{p}$ \\
\cline { 2 - 5 } Constant & $\mathrm{B}$ & S. Error & $\beta$ & & \\
\hline Flexible working & 2,231 & 0,501 & & 4,458 & 0,000 \\
\hline
\end{tabular}

Dependent Variable: Job Satisfaction

Accordingly, flexible working has a significant effect on job satisfaction $(t=2,454 ; p=0,016)$. The regression equation between flexible working $(\mathrm{X})$ and job satisfaction $(\mathrm{Y})$ was found to be $\mathrm{Y}=2,454+0,321 \mathrm{X}$. In addition, the variance $(\mathrm{r} 2)$ explained by the variables on each other is $7 \%$. 
Based on this result, the hypothesis " $\mathrm{H} 2$ : Flexible working positively affects the job satisfaction of employees is not statistically rejected.

The following results were obtained from our analyzes created to test the mediating role of organizational commitment in the effect of flexible working on job satisfaction.

According to the results of the regression analysis indicated in Table 4., the effect of flexible working on job satisfaction was found to be significant $(B=0.321$; Beta $=0.265 ; \mathrm{p}=0.016$ ).

According to the results of the regression analysis indicated in Table 3., the effect of flexible working on organizational commitment was found to be significant $(B=0.450$; Beta $=0.430 ; p$ $=0.000)$.

\subsection{The Mediating Effect Of Organizational Commitment On Relationship Between Flexible Working And Job Satisfaction}

In order for the final requirement of the model to be realized, when flexible working and organizational commitment are included in the analysis, the impact of flexible working on job satisfaction should be reduced or completely eliminated. To determine this condition, multiple regression analysis in Table 5. was performed.

Table 5. The Result Of Multiple Regression Analysis Examining The Mediating Role Of Organizational Commitment on relationship between Flexible Working and Job Satisfaction

\begin{tabular}{|l|l|l|l|l|l|}
\hline \multirow{2}{*}{$\begin{array}{l}\text { Regression Model } \\
(\mathrm{r}=0,556 ; \mathrm{r} 2=0,309\end{array}$} & \multicolumn{2}{|l|}{$\begin{array}{l}\text { Non-Standardized } \\
\text { Parameters }\end{array}$} & $\begin{array}{l}\text { Standardized } \\
\text { Parameters }\end{array}$ & $\mathrm{t}$ & $\mathrm{p}$ \\
\cline { 2 - 5 } & $\mathrm{B}$ & S. Hata & $\mathrm{B}$ & \\
\hline Constant & 0,937 & 0,500 & & 1,876 & 0,064 \\
\hline Organizational Com. & 0,627 & 0,120 & 0,542 & 5,234 & 0,000 \\
\hline Flexible working & 0,038 & 0,126 & 0,032 & 0,306 & 0,761 \\
\hline
\end{tabular}

Regression analysis to determine the mediating role of Organizational Commitment in the relationship between Flexible Working and Job Satisfaction was found to be statistically significant $(F=17,699 ; p=0,000)$. When the independent variables, Flexible Working and Organizational Commitment were analyzed, it was seen that Organizational Commitment was significant $(t=5.234, p=0.000)$, but Flexible Working was not significant $(t=0.306, p=0.761)$. In this case, with the addition of Organizational Commitment, the relationship between Flexible Working and Job Satisfaction turned out to be meaningless. Therefore, Organizational Commitment mediates in the relationship between, Flexible Working and Job Satisfaction.

Based on the findings, the hypothesis " $\mathrm{H} 3$ : Organizational Commitment has a mediating role in the effect of Flexible Working on Job Satisfaction is not statistically rejected. 


\subsection{Summary}

The findings of the effects of flexible working on the organizational commitment and job satisfaction and mediating role of Organizational Commitment are summarized in Figure 2.

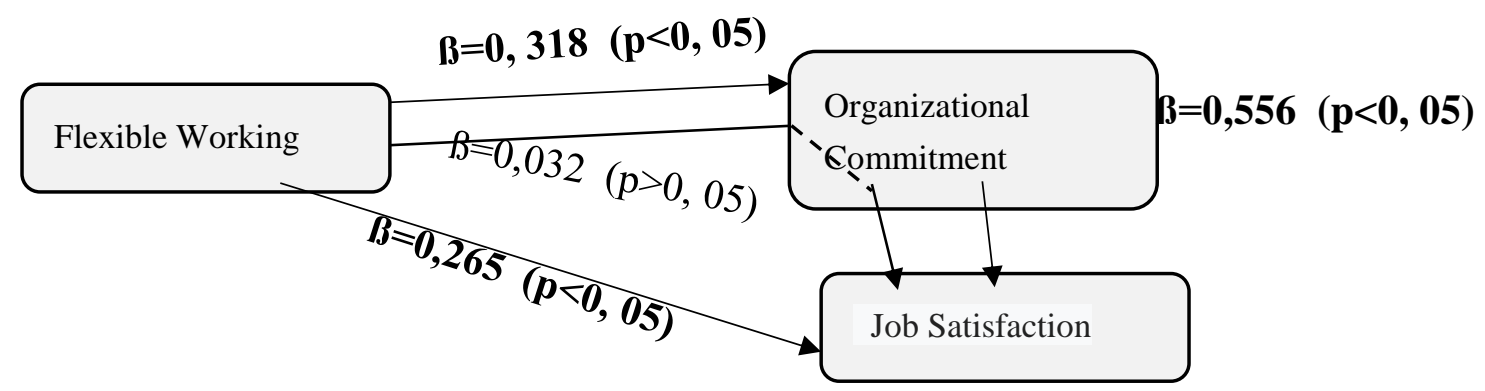

Figure 2. Research Summary (The Effect of Flexible Work on Organizational Commitment and Job Satisfaction and Intermediation Role of Organizational Commitment)

\subsection{Analysis of Flexible Working, Organizational Commitment and Job Satisfaction According to Demographic Variables}

In this section, whether flexible working, organizational commitment and job satisfaction differ significantly or not according to demographic variables are examined under subheadings.

In order to determine the relationship between socio-demographic characteristics of the participants and the variables of the research, difference analyzes were conducted. One-way analysis of variance (One-Way ANOVA) was used to determine the difference between the groups in the comparison of quantitative data.

Gender: When the group averages are considered, it is seen that women's perception of flexible working is not an obstacle in terms of career development and job relationships and job satisfaction is higher.

Age; Flexible working and organizational commitment did not differ significantly by age ( $\mathrm{p}>$ $0,05)$. However, job satisfaction showed a significant difference according to age ( $\mathrm{p}<0.05)$. As a result of the multiple comparison (post-hoc) test, it was found that job satisfaction of participants aged 20 years and younger was higher than that of participants aged 31-40 years.

Educational Status; Organizational commitment did not differ significantly according to educational status $(p>0,05)$. However, flexible working and job satisfaction showed a significant difference according to education level $(\mathrm{p}<0,05)$. As a result of the multiple comparison (post-hoc) test, it was found that the positive perceptions and job satisfaction of university graduates and upper were higher than those of high school and vocational high school graduates.

Marital status; Flexible Working, Organizational Commitment and Job Satisfaction perceptions did not differ according to marital status ( $p>0,05)$.

Total Seniority; Flexible Working, Organizational Commitment and Job Satisfaction perceptions did not differ according to seniority ( $p>0,05)$.

Seniority; Flexible Working, Organizational Commitment and Job Satisfaction perceptions did not differ according to seniority ( $\mathrm{p}>0,05)$. 
Place of Work: The positive perception of Flexible Working and Job Satisfaction of employees in Regional Directorate and General Directorate were significantly higher than those of Factory employees $(\mathrm{p}<0,05)$.

\section{Conclusion}

Globalization, intense economic competition, and change in information and production technologies affect both employees and businesses. Employers aim to increase their employees productivity, efficiency and loyalty by providing better working conditions to their employees, through flexible working arrangements.

Starting from this, 82 employees participated in this study which was conducted to determine the effect of flexible working on job satisfaction and organizational commitment and the role of organizational commitment in the relationship between flexible working and job satisfaction. Employees include participants of all ages, from 20 years of age and over to 50 years and older. Among the participants, every level of education from high school graduates to doctoral graduates is represented and 55\% of them are at least university graduated or higher educated. In addition, when marital status is examined, two thirds of the respondents are married and approximately $60 \%$ have children.

Approximately half of the participants have a total seniority year of less than 10 years and half of them have more than 10 years.

Seniority in the workplaces they work for is less than 5 years in half of the participants and 5 years and over in the other half. In addition, approximately 60\% work in the Head Office, Regional Directorate and Branches / Offices. The monthly fee is between 2,200-5,000 TL in half of the participants. The minimum wage is only $2.6 \%$. The remaining participants receive a monthly salary of more than TL 5,000. In addition, approximately $35 \%$ of the participants can determine their working hours themselves and already benefit from the flexibility of the workplace. The ratio of those who do not benefit from them is about $40 \%$ for working hours and about $33 \%$ for working place.

The first result of the research is that employees have a positive attitude towards flexible working arrangements. The participants think that flexible working arrangements in general contribute to the work - life balance and do not create career obstacles in working life and obstacles in relations with managers and colleagues. In particular, they believe that flexible working arrangements play an important role in fulfilling family responsibilities, being more committed to workplace tasks and balancing life responsibilities.

In addition, when the relationships between flexible working, job satisfaction and organizational commitment were examined, important results were obtained. First, with flexible working; There was a statistically low positive correlation between job satisfaction $(\mathrm{p}<0.05)$ and a statistically moderate positive correlation between organizational commitment. As a matter of fact, $8 \%$ of job satisfaction; $18.5 \%$ of the organizational commitment can be caused by flexible working. Therefore, it was concluded that flexible working arrangements had a significant effect on both job satisfaction and organizational commitment levels.

Regarding the mediation role of Organizational Commitment, it is concluded that organizational commitment is mediating role in the effect of flexible working on job satisfaction. 
This is because the relationship between flexible working and job satisfaction has become statistically insignificant with the inclusion of organizational commitment. Therefore, organizational commitment has a mediating role in the effect of flexible working on job satisfaction, and organizational commitment has been found to be complete mediator "variable in this relationship. In summary, while flexible working increases job satisfaction and organizational commitment, the increase in organizational commitment increases job satisfaction.

Flexible working, organizational commitment and job satisfaction showed significant differences with respect to demographic variables.

In terms of Flexible Working perception; there is no significant difference according to gender, age, marital status and seniority ( $\mathrm{p}>0.05$ ). However, positive evaluations regarding flexible work are higher for employees who have bachelor's degree or higher than those who have graduated from High School and Vocational School. ( $p<0,05$ ). In addition, it was observed that the employees working at the General Directorate and Regional Directorate had a more flexible working evaluation than the factory employees, those with higher monthly wages had a more favorable flexible work evaluation than those with low wagesa and those who can determine working hours flexibility and those benefiting from workplace flexibility have a more favorable flexible work evaluation than those who do not benefit from them.

Organizational Commitment did not differ according to gender, age, education level, marital status, total seniority, seniority in current workplace, monthly salary and working hours flexibility ( $p>0,05)$. However, it is seen that employees who work in the Regional Directorates have more organizational commitment than Factory employees and employees who take advantage of workplace flexibility have more organizational commitment than others $(\mathrm{p}<0.05)$.

Job Satisfaction did not differ in terms of gender, marital status and seniority ( $p>0.05)$. However, those under the age of 20 have more job satisfaction than those in the age range of 31-40, employees in Head Office and Regional Directorate or Branches have more job satisfaction than Factory employees; the monthly salary is between 5,000 and 10,000 TL, and between 2,200 and 5,000 TL; have more job satisfaction It was seen that those who can determine the working hours themselves and who benefit from the flexibility of the work place have more job satisfaction than those who do not $(\mathrm{p}<0.05)$.

The intensity of working hours and difficult working conditions makes the attracting and retaining of talented employees difficult for logistics firms. The study present the effect of flexible working arrangements on increasing job satisfaction and employee loyalty.

Therefore, in order to attract talented employees and to increase women employees in the sector, to be the leader in international competition as being an employee friendly company, to apply flexible working arrangements is unavoidable for logistics firms.

\section{References}

Akat, İ., \& Budak, G. (2002). İşletme Yönetimi. İzmir.

Albion, M. (2004). A Measure of Attitudes Towards Flexible Work Options,. Australian J. of Management 29(2), 275-294.

Altunışık, R. (2010). Sosyal Bilimlerde Araştırma Yöntemleri: SPSS uygulamalı. Sakarya Yayıncilik. 
Ardıç, K., \& Baş, T. (2001). Kamu ve Vakıf Üniversitelerindeki Akademik Personelin İs Tatmin Düzeyinin Karşılaştırılması. 9.Ulusal Yönetim ve Organizasyon Kongresi. İstanbul.

Atkinson, J. (1987). Flexibility or Fragmentation? The United Kingdom Labour Market in the Eighties. Labour and Society, 87-105.

Bartel, A. (1981). Race Differences in Job Satisfaction: A Reappraisal, The Journal of Human Resources, 294-303.

Beer, M. (1964). Organizational Size and Job Stisfaction. The Academy of Managment Journal , 34-44.

Benner, C. (2002). Works in the New Economy: Flexible Labour Markets in Silicon Valley, London: Basil Blackwell, p. 23. London: Basil Blackwell.

Bennett, R. (1994). Organisational Behaviour. London: Pitman Yayınları.

Boyer, R. (1990). The Capital Labor Relations in OECD Countries: from the Fordist "Golden Age" to Contrasted National Trajectories. Paris: Working Paper Cepremap.

Burchell, B., Ladipo, D., \& Wilkinson. (2002). Job Insecurity and Work Intensification. London: Routledge Publ.

Büyüköztürk, Ş. (2011). Sosyal Bilimler İçin Veri Analizi El Kitabı. Ankara: Pegem Akademi.

Davis, K. (1988). İşletmede İnsan Davranış1:Örgütsel Davranış, Çev:Kemal. İstanbul: İstanbul Üniversitesi İşletme .

Ekin, N. (1999). Esneklik Çağı. Mercek Özel Sayı , 6-16.

Gilmore, S., \& Williams, S. (2009). Human Resource Management. New York: Oxford University Press.

Günay, İ. (2004). Çalışma Sürelerinde Esneklik. Kamu İş Dergisi , 18.

Gündoğan, T. (2009). Örgütsel Bağlılık. Uzmanlık Yeterlilik Tezi, Türkiye Cumhuriyet Merkez Bankası. Ankara.

Kalleberg, A. (1977). Work Values and Job Rewards: A Theroty of Job Satisfaction. American Sociological Review, 124-143.

Karakoyunlu, E. (1999). Esneklik. MESS Mercek Dergisi, Esneklik Özel Sayısı, 23-24.

Karcıŏlu, F., Timuroğlu, M., \& Çınar, O. (2009). Örgütsel İletişim ve İş Tatmini İlişkisi, Bir Uygulama. Yönetim Dergisi, 63.

Koçel, T. (2007). İşletme Yöneticiliği. İstanbul: Arıkan Basım Yayın.

Mathieu, J., \& Zajac, D. (1990). A Review and Meta- Analysis of the Antecedents, Correlates, and Consequences of Organizational Commitment. Psychological Bulletein, 108(2), 171-194.

Meral, Y. (2018). İşletme Birleşmelerinde Özdeşleşme, Güven, İletişim Kültür ve Süreç Adaletinin, İş Doyumu Ve Banka Birleşmesi Sonrası Yeni Özdeşleşme Üzerindeki Etkileri. İstanbul: Beta Basım Yayım Dağıtım A.Ş.

Meulders, D., \& Wilkin, L. (1987). Labor Market Flexibility: Critical Introduction to the Analysis of a Concept. Labor and Society, 8.

Michon, F. (1987). Time and flexibility- Working time in the debate on flexibility.

Rubery, J., Tarling, R., \& Wilkinson, F. (1987). "Flexibility, Marketing the Organization of Production". Labour and Society, 131-156.

Schermerhorn, J., \& Bond, M. (1997). Cross-Cultural Leadership Dynamics in Collectivism and High Power Distance Settings. Leadership and Organization Development Journal , 187-193.

Seyyar, A., \& Öz, C. (2007). İnsan Kaynakları Terimleri Ansiklopedik Sözlük. İstanbul: Değişim Yayınları. 
Steers, R., \& Black, S. (1994). Organizational Behavior. New York: Harper Collins College Yayınlar1.

Stone, K. (2004). From Widget to Digits: Employment Regulation for the Changing Workplace. Cambridge: Cambridge University Press.

Weiss, D., Dawis, R., England, G., \& Lofquist, L. (1967). Manual for the Minnesota Satisfaction Questionnaire. Minnesota Studies in Vocational Rehabilitation XII.

Yavuz, A. (1995). Esnek Çalışma ve Endüstri İlişkilerine Etkisi. Ankara. 